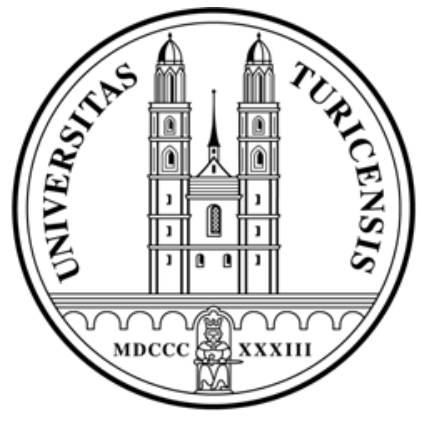

Institute for Empirical Research in Economics

University of Zurich

Working Paper Series

ISSN 1424-0459

Working Paper No. 366

Effects of Firm Size and Business Cycle on Earning

Losses of Displaced Workers

Oliver Ruf

April 2008 


\title{
Effects of Firm Size And Business Cycle on EARning Losses of Displaced Workers
}

\author{
Oliver Ruf*, University of Zürich
}

February 2008

\begin{abstract}
This paper analyzes labor market success of workers who are displaced in boom versus recession periods. Moreover, the empirical analysis contrasts workers from small firms and large firms. The idea is that displacement carries no information about workers' productivity in large firms but is a signal of low productivity in small firms. This signal is stronger when the plant closure occurs in a boom period than in a recession period. Results indicate that the (i) state of the business cycle is important for influence the effect of displacement on labor market success and (ii) the effect differs by the size of the firm. In large firms, displaced workers suffer from larger earning losses when displacement occurs in recession compared to boom, the opposite result is found for workers displaced from small firms.
\end{abstract}

JEL-Classification: E32, J64, J65

Keywords: displaced workers, wage losses, business cycle, size of the firm

*Thanks to Joshua Angrist, Andrea Ichino, Andreas Kuhn, Peter J, Kuhn, Rafael Lalive, Ian Walker, Rudolf Winter-Ebmer and Josef Zweimueller for helpful comments and discussions. Financial support by the Swiss National Science Foundation (No.100012-103970) is gratefully acknowledged. Address: Oliver Ruf, University of Zurich, Institute for Empirical Research in Economics, Bluemlisalpstr. 10, CH-8006 Zürich, oliruf@iew.uzh.ch. 
"Capitalism without bankruptcy

is like Christianity without hell."

Frank Borman, retired NASA astronaut

\section{Introduction}

All of Switzerland was paralyzed by the grounding of Swissair, our national airline. We were shorn of the illusion that the white cross on the logo of our airline stood for stability and security. Nearly everyone around Zurich knows someone who was affected by the grounding of Swissair. Fortunately the government and the economy reacted, for Swiss circumstances, very rapidly by providing billions to build up a new airline out of the remains of Swissair. In doing so further negative consequences could be avoided, such as the potential demise of many intermediate firms dependent on Swissair.

For decades, economists and politicians alike have concerned themselves with the problem of workers loosing their jobs due to events beyond their control. Displaced workers suffer substantial earnings losses after a plant closure (e.g. Flaim and Sehgal, 1985; Hamermesh, 1989; Addison and Portugal, 1989; Ruhm, 1991). Because of the loss of firm-specific human capital, internal wages lie above alternative wages (Hamermesh, 1987). The earnings losses of displaced workers even hold in the long run (Jacobson et al., 1993; Stevens, 1997). Contrary to workers who have been laid-off, a worker's displacement does not signal that he is less productive. Displaced workers have higher re-employment wages and shorter unemployment spells than laid-off workers (Gibbons and Katz, 1991). The idea behind this signaling hypothesis is that an individual worker is unlikely to have contributed to a plant closure, whereas being laid off is seen as a sign of low productivity.

This chapter proposes that the individual contribution to a plant closure and thus the signal about a worker's productivity is not necessarily insignificant and it depends on the size of the former employer and the business cycle. In general, this chapter argues first, that the probability that a plant closure is driven by a negative demand shock is larger in recessions than in booms and second, that firm performance is closely related to the effort exerted by an individual worker in small firms but not in large firms. Consider an economy with a asymmetric flow of information, where the workers' productivity is not observable to the employer. A new employer of a displaced worker would have no 
information about this workers' productivity besides the fact that his previous employer has closed down. Consider furthermore that this worker's previous firm was a one-man company that went bankrupt in an economic environment which was steadily improving. In this extreme example it seems natural that the individual contribution of this single worker to the plant closure cannot be ignored from the labor market. The question is: what does the new employer learn about the productivity of the worker, when his only information is that the worker's previous firm has gone bankrupt? This chapter argues that when a worker who was displaced from a small firm is looking for a new job in a boom period, the new employer infers that the worker is of low productivity. Workers displaced from a large firm or during a recession period do not carry such a negative signal.

The empirical analysis will contrast earnings losses for workers displaced in a boom from workers displaced in a recession and furthermore distinguish between workers displaced from small firms and large firms. This chapter will use workers who have been displaced from large firms as a benchmark, where individuals' contribution to the plant closure and thus the signal on workers productivity is almost zero. Because re-employment real wages are lower in a recession than in a boom (Dunlop, 1938; Tarshis, 1939; Baker et al., 1994; Barlevy, 2001), workers getting displaced from large firms should suffer larger earnings losses when the plant closure occurs in a recession than in a boom. This argument also applies to small firms. In addition, workers who have been displaced from small firms also carry a negative signal because they would have had more influence on the success of the firm. One would expect that this negative signal should be worse in a boom than in a recession and thus induce larger earnings losses when the plant closure occurs in a boom. The net effect of the business cycle on future earnings for workers getting displaced from small firms is ambiguous.

The empirical analysis is based on a large administrative data set covering all Austrian private sector workers and their quarterly (un)-employment and earnings history from 1972 to 2001. A unique feature of the data is that by observing the size of the firm over time the exact date of each plant closure can be determined, this allowing one to compare earnings losses of workers displaced in a boom with workers displaced in a recession. Additionally, plant closing is observed at the firm level, which allows one to contrast large plant closure firms from small plant closure firms. 
The main results of this chapter are, first, that workers getting displaced from large firms suffer larger earnings losses when they get displaced at the beginning of a recession period rather than at the beginning of a boom period. Separating the earnings effects into a wage and an unemployment effect results indicate that the probability of finding a new job after displacement is larger in a boom than in a recession. Wages are, however, not affected. Thus the large earnings losses in the recession period are driven by the accordingly larger fraction of unemployed displaced workers. These findings for workers displaced from large firms holds true during the entire post-displacement time period of six years. Second, workers who have been displaced from small firms experience significantly higher declines in earnings when they lose their job at the beginning of a boom period. This is in contrast to the findings for the large firms. Differences in the earnings losses between boom and recession are largely driven by the wages. Workers displaced from small firms suffer substantially larger declines in wages when the plant closure occurs at the beginning of a boom period. The probability of finding a new job after displacement is hardly affected by the business cycle. Third, there are no significant differences in pre-displacement earnings between boom and recession, neither for large firms nor for small firms. Thus the difference findings for the earnings losses during a boom versus a recession are not driven by ex-ante heterogeneity of workers and firms.

This chapter is organized as follows: Section 2 gives a short overview of related literature. Section 3 presents the data source and defines the sample of plant closure workers and the control sample of non plant closure workers respectively. Further, this section gives a short descriptive comparison of the earnings losses during a boom versus a recession, separately for workers displaced from large firms and workers displaced from small firms. Section 4 introduces different measures to capture the losses due to a plant closure and presents the statistical models used in this chapter. The results are shown and discussed in section 5. Section 6 concludes.

\section{$2 \quad$ Related Literature}

There are many studies analyzing long-term earnings losses of displaced workers. One of the most exhaustive studies is one from Jacobson et al. (1993). The authors use longitudinal data containing quarterly earnings histories for a large number of high 
tenure displaced and non-displaced workers from Pennsylvania, extending from 1974 to 1986. The authors find significant long-term earnings losses for the five years following the plant closure for high tenure workers. Further, they find that the earnings losses of displaced workers begin mounting before their displacement and depends only minimally on their age and sex. Jacobson et al. (1993) also find strong evidence that the earnings losses depend on the local labor market conditions. Workers displaced in a region with weak labor market conditions suffer higher earnings losses than workers displaced in a region with better labor market conditions. Stevens (1997) finds for the U.S. , in connection with a national data set based on a survey, that even six or more years after the plant closure displaced workers' earnings lie significantly below their expected levels. Further, she shows that a big part of these earnings losses can be explained by additional job losses following an initial displacement. Bender et al. (2002) compare, among other things, the wage profile of displaced workers after their job loss with the wages they earned right before the plant closure, using French and German data. In Germany, displaced workers earn significantly less in the three years after the plant closure but the earnings loss becomes insignificant after four years. In France, displaced workers earn even more in the first three years after the plant closure than directly before the plant closure. One explanation could be that high-wage workers find a new job earlier. The earnings difference becomes insignificant after four years as well. Thus, in contrast to the results from Jacobson et al. (1993) the earnings losses in France and Germany disappear in the long run. The reason for this may be the much more regulated labor markets in France and Germany, compared to in the United States.

Gibbons and Katz (1991) offer another approach by comparing the labor market success of plant closure workers with laid-off workers. They provide a theoretical and an empirical analysis of an asymmetric information model of layoffs. The idea behind their paper is that employers have private information concerning their employees' productivity and they are able to choose who to lay off. Accordingly, the market infers that laid-off workers are of low productivity and offers them lower wages in their next job. In other words, laid-off workers carry a negative signal concerning their productivity. The authors assume that workers displaced by a plant closure, in contrast, carry no signal concerning to their productivity, because the worker's individual contribution to the plant closure of a firm is negligible. Therefore the authors predict higher re-employment 
wages for plant closure workers than for laid-off worker. They confirm this prediction using the 1984-1986 Displaced Workers Survey (DWS) as a supplement of the Current Population Survey (CPS).

There is further literature which analysis either the effect of the business cycle or the effect of the size of the former employer. While not distinguishing between small firms and large firms, Nakamura (2004) develops a theoretical model in which displacement arises from a combination of selection and bad luck. The idea is that in every period some workers get laid off due to their low productivity, while the number of laid off workers due to bad luck would be higher during a recession. The proportion of workers who are laid off due to their low productivity would thus be larger during a boom. This implies that workers who get laid off in a recession are, on average, less adversely selected than those laid off during a boom. If the productivity of a worker is not observable to employers and the signaling effect varies over time, wage losses should also vary over time. Using the DWS as a supplement to the CPS she finds that the overall unemployment rate at the time of the job displacement has a significant positive effect on individuals' earnings losses. Farber (2005) also finds strong evidence that earnings losses of displaced workers are pro-cyclical to the business cycle. Also using the DWS and the CPS he finds earnings losses of about 7\% during a recession as opposed to earnings losses of about $17 \%$ during a boom. Winter-Ebmer (2001) shows, using a large Austrian administrative data set, that larger firms not only pay higher wages but also offer more stable employment conditions. Krashinsky (2002) shows, using the National Longitudinal Survey of Youth, that the difference between earnings losses of laid off workers compared with those of displaced workers found by Gibbons and Katz (1991) becomes insignificant after controlling for the size of the former and the new employer.

Farber (1996), Kletzer (1998) and Abbring et al. (2002) investigate the effect of the business cycle on the displacement rate. For displaced workers, defined as permanent layoffs, the displacement rate is more or less anti-cyclical to the business cycle. The displacement rate, which includes only those workers displaced due to a plant closure, shows little variation over time. 


\section{Data and Descriptive Analysis}

\subsection{Data}

The data source for the empirical analysis in this chapter is the "Austrian Social Security Database" (ASSD $\left.{ }^{1}\right)$, which contains detailed information about individuals' employmentunemployment- and earnings-history and several demographic characteristics such as age, gender, and broad occupation. The ASSD also contains detailed information on the employer, such as the size of the firm, the geographical location and the industry affiliation. The data set is unique in the following respects: first, one can exactly determine the date of a plant closure and thus precisely analyze workers' earnings losses over time. Second, one can observe plant closure at the firm level, allowing one to distinguish between small firms and large firms. This allows one to also control for firm specific characteristics in addition to individual worker's characteristics.

Individual earnings are available as earned income per workday. Earnings are measured in Euro and deflated by the consumer price index from 1986. For the purposes of this study, the 10th of February, May, August and November were used as quarter reference dates ${ }^{2}$. Because the data was originally collected for Social Security purposes, there are also some disadvantages. The available earnings are right censored; about $15 \%$ of the workers have earnings above the upper censoring level, which varies over time. The data also does not contain any information about full or part time employment. However, the focus of this chapter is on income. The censoring may be problem. Yet, because workers suffer an earnings loss due to the plant closure, the fraction of censored wages will be larger in the group of non plant closure workers. This means the differences between the earnings of the plant closure (PC) workers and the non plant closure (NPC) workers will be attenuated due to the censored earnings.

The ASSD contains no direct information about plant closures. Yet, they can be constructed by analyzing the size of companies over time. A company is defined as a plant closure firm at the reference date $t$ when two conditions are satisfied: (i) the firm disappears ${ }^{3}$ between the reference dates $t$ and $t+1$ and does not re-emerge during the

\footnotetext{
${ }^{1}$ For a detailed description of the ASSD see Kuhn and Ruf (2006)

${ }^{2}$ This setup implies that the data includes only information of the according reference dates.

${ }^{3} \mathrm{~A}$ firm disappears from the data, if it has no employees between $t$ and $t+1$.
} 
following year ${ }^{4}$ (ii) and less than $50 \%$ of the employees of a company find a new job with the same new employer. The latter criterion makes sure that company acquisitions are not erroneously classified as plant closures. In this chapter a worker counts as a PC worker at time $t$ when he still works in the plant that goes bankrupt within the next quarter. That is, all PC workers will be displaced ${ }^{5}$ within the next three months.

\subsection{Sample Design}

The aim of this chapter is to analyze the effect of job displacement on the future wage profile of displaced workers at two different points in the business cycle. Figure 1 shows the yearly growth rates of the real GDP (solid line) and the unemployment rates (dashed line), which are used as indicators for the business cycle.

\section{Figure 1}

As discussed in the introduction, the two points in time should be selected such that in one of them the economic situation steadily improves and in the other the economic conditions continuously deteriorate. In the statistical analyses, both a boom and a recession is made up of a period of eight consecutive quarters. The period 1987/1988 is followed by 5 years with relatively low unemployment rates (below 6\%) and growth rates of the real GDP above $2 \%$. This point in time, which is followed by a period where the economy expands relatively rapidly, is selected as the boom period. The period $1991 / 1992$ is followed by six years with unemployment rates above $6 \%$, and four years with growth rates of the real GDP below $2 \%^{6}$. This time period with relatively higher unemployment rates and a more slowly expanding economy is selected as the recession period. Therefore by comparing the earnings losses between the years following the plant closure, a typical boom period is compared with a typical recession period. For each of these points in time a sample of workers is generated. Each of these samples contains all the workers who were employed at least at one quarter reference date in the according time period. The workers are split up in PC workers and NPC workers. The group of PC workers contains workers who were employed at least at one of the eight quarter

\footnotetext{
${ }^{4}$ This condition is set to one year, because the firm numbers were assigned anew after two years. That is, under the same firm number a completely new firm may emerge after two years.

${ }^{5}$ I will use plant closure and displacement as synonyms in this chapter.

${ }^{6}$ Expect for the year 1994, where the growth rate of the real GDP amounts to $2.4 \%$.
} 
reference dates in a plant closure firm. The group of NPC workers, used as the control group, contains workers who have never been employed in a plant closure firm during the same time period.

The data set includes the quarterly earning profile of each worker over six pre- and six post-displacement years for both points in time. To ensure that most of the workers exhibit earnings during this period and to avoid the problem of early retirement ${ }^{7}$, the samples are restricted to prime-age workers aged 25-48. To compare the group of workers between the two points in time, the workers should have comparable costs of displacement. Workers who often change their firms and thus are used to being unemployed and looking for a new job would be less affected by an unexpected job loss than attached workers who want to keep their job. Furthermore, workers who leave a distressed firm before the bankruptcy is apparent, have different earning profiles than worker who stay until the end (Bowlus and Vilhuber, 2002; Schwerdt, 2005). Accordingly, the sample is restricted to attached workers, with at least two years of tenure. An additional advantage of this restriction is that workers who are only seasonally unemployed are dropped too. ${ }^{8}$ In addition, all observations without information about industry or region were excluded from the sample.

Table 1 shows the number of PC workers who fullfill the restrictions discussed above, listed according to the size of their firms. The numbers in parentheses correspond to the number of the involved firms. ${ }^{9}$ Up to the size of firms with 100 employees the number of PC workers does not differ much between boom and recession. But with the bigger firms come larger differences. In order to have as few differences as possible between boom and recession, firms with more than 100 employees were excluded. Further, the employees should have comparable information about the future financial problems of their company before the plant closure. The smaller a company the better would be the employees' information about the imminent bankruptcy of their employer. Thus, the large group of firms with less than five employees is excluded from the samples. An

\footnotetext{
${ }^{7}$ In the ASSD we observe early retirement already for 55 years old worker.

${ }^{8}$ In Austria there are a lot of seasonal workers. For example, in the constructing industry many workers are disbanding in the unemployment during the winter because of the smaller volume of orders. For more detailed information about seasonal workers and the restriction of two years of tenure see Ruf (2004).

${ }^{9}$ At first sight it's confusing that in the firm in the group of 500 - 999 employees only 145 workers were employed. At second sight, it gets clear that only 145 workers of this firm are aged 25-48 and have at least two years of tenure.
} 
other reason why firms with less than five employees were excluded, is that it is difficult to identify a plant closure for tiny firms. To analyze different earnings losses depend on the size of the former employer, this article distinguishes between small firms, which employ between five and nine workers, and large firms, which employ between ten and one hundred workers.

Table 1

For the empirical analysis a $2 \%$ random sample of the NPC workers and all the PC workers were used. After imposing all the restrictions mentioned in this section there remain for the boom period: 1,035 $(9,596)$ PC (NPC) workers in the sample of small firms and 1,167 $(37,933)$ in the sample of large firms. For the recession period: 1,144 $(9,640)$ in the sample of small firms and $1,191(39,198)$ in the sample of large firms

\subsection{Descriptive Analysis}

First, I calculate the average earning differences of the PC workers minus the NPC workers for the six pre- and the six post-displacement years. The left subfigure of figure 2 shows the average differences for the large firms and the right column those for the small firms. The differences in earnings are computed on the vertical axis and the years since displacement on the horizontal axis. The solid lines correspond to the differences in the boom period whereas the dashed lines correspond to those of the recession period.

\section{Figure 2}

In both points in time, workers displaced from large firms earn on average a little less than the NPC workers during the six pre-displacement years. The differences are slightly larger during a recession than during a boom. The PC workers suffer a large earnings loss during the first years; subsequently the difference in earnings to the NPC workers gets smaller over time. Workers displaced from large firms suffer larger earnings losses over the whole post-displacement period when the plant closure occurs during a recession than during a boom.

For workers displaced from small firms the differences in earnings between the PC workers and the NPC workers is almost zero during the six pre-displacement years. The path of the earnings losses in the post-displacement years appears similar to the results 
for the large firms. But in contrast to workers displaced from large firms, those displaced from small firms suffer larger earnings losses over the whole post-displacement period when the plant closure occurs during a boom than during a recession. Summed up, during a recession workers suffer larger earnings losses, when they are displaced from large firms, whereas during a boom the earnings losses are larger for workers displaced from small firms.

Table 2

Table 2 shows the average characteristics of workers and firms, for each group correspondingly. There are only small differences between the average $\mathrm{PC}$ worker and the average NPC worker. In all the samples PC workers are on average older than the NPC workers; nevertheless PC workers are less attached to their firms. In the sample of small firms, seasonal firms ${ }^{10}$ have a higher probability to go bankrupt at the beginning of a boom period than non seasonal firms, whereas during a recession there is almost no such difference. It is unclear, however, whether the ex ante heterogeneity of workers and firms of the different groups are responsible for the differences found in this section. Therefore, in the next section, regressions are made which control for these ex ante heterogeneities.

\section{Identification and Statistical Models}

The aim of this chapter is to determine if earnings losses due to a plant closure depend on the size of the former employer and the business cycle. To analyze this question the empirical part distinguishes four groups of workers: those who are (i) employed in large firms during a recession, (ii) employed in large firms during a boom, (iii) employed in small firms during a recession and (iv) employed in small firms during a boom. Subsection 4.1 discusses how earnings losses are identified. Subsection 4.2 presents separate regressions, which, on the one hand, are used to estimate the earnings losses for the four groups and, on the other hand, to estimate the differences in the earnings losses between boom and recession periods, for large and small firms respectively.

\footnotetext{
${ }^{10}$ Seasonal firms includes the building industry and the tourist sector.
} 


\subsection{Identification of the Losses due to Plant Closure}

A decline in earnings may result from a combined effect of a decline in wages and a larger probability to be unemployed. This means that a lower expected income for a group of workers can be the result of a lower average wage and/or more unemployed workers with zero income within this group. This can be written as follows:

$$
E_{g t}\left(\text { earning }_{i}\right)=E_{g t}\left(\text { wage }_{i} \mid U_{i}=0\right) \cdot E_{g t}\left(U_{i}=0\right) .
$$

Here, earning $g_{i}$ corresponds to the earning of individual $i$ in a specific year before or after displacement. Thus, $E_{g t}\left(\right.$ earning $\left._{i}\right)$ corresponds to the expected earnings of a group of workers $g$ at time $t$. This expectation can be written as the product of the expected wage of all employed workers of group $g$ at time $t E_{g t}\left(\right.$ wage $\left._{i} \mid U_{i}=0\right)$ multiplied with the expected probability to be employed within this group of workers $E_{g t}\left(U_{i}=0\right)$. From here onwards, the effect of the plant closure on the probability to be unemployed will be called the unemployment probability (UP) effect and the effect on the wage, the wage effect. For a change in expected wages there are two sources; a selection effect and a net wage effect. The selection effect occurs because more productive workers with higher average wages find a new job faster than less productive workers with lower wages. The net wage effect reflects changes in the wage of a specific worker, wage ${ }_{i}$, relative to his average wage of the two years prior to displacement $\overline{\operatorname{wage}}_{i}{ }^{11}$. This can be written as follows:

$$
E_{g t}\left(\text { wage }_{i} \mid U_{i}=0\right)=E_{g t}\left(\overline{w a g e}_{i} \mid U_{i}=0\right)+E_{g t}\left(\text { wage }_{i}-\overline{w a g e}_{i} \mid U_{i}=0\right) .
$$

The variable $\overline{w a g e}_{i}$ can be used as a proxy of productivity for this worker (which is not observed in the ASSD). Changes in $E_{g t}\left(\overline{w a g e}_{i} \mid U_{i}=0\right)$ are only induced by variations in the composition of employed workers. This is termed the selection effect. $E_{g t}\left(w_{a g} e_{i}-\right.$ $\left.\overline{\operatorname{wage}}_{i} \mid U_{i}=0\right)$ captures the net wage decline for employed workers. This is the net wage effect, which is unaffected by time invariant unobserved individual characteristics.

\footnotetext{
${ }^{11}$ During this two years all the individuals are employed, because a tenure of at least two years is required to be included in the sample.
} 


\subsection{Statistical Models}

It is not clear if the ex-ante heterogeneity between workers and their firms is responsible for the observed differences in average earnings discussed in the descriptive part. To take this into account, one can estimate the following linear regression model for each group of workers with:

$$
W_{i t}=\alpha+\left(p c_{i} \cdot y_{t}\right)^{\prime} \beta+y_{t}^{\prime} \gamma+x_{i}^{\prime} \delta+f_{i}^{\prime} \eta+q_{i}^{\prime} \theta+\epsilon_{i t}
$$

where $W_{i t}$ corresponds to one of the variables discussed above. (i.e., earnings $s_{i t}$, wages $s_{i t}$, $U P_{i t}, \overline{w a g e}_{i}$ or $\left.\left(w a g e_{i t}-\overline{w a g e}_{i}\right)\right)$. Earnings and wages are deflated by the average ${ }^{12}$. $p c_{i}$ is a dummy variable taking on the value one for $\mathrm{PC}$ workers and zero otherwise. $y_{t}$ is a vector of dummy variables representing the years since displacement (from six years before to six years after displacement). The vector $x_{i t}$ includes individual characteristics like age, age squared, gender, tenure, tenure squared and a dummy variable for blue collar workers in order to control for the ex-ante heterogeneity of workers. The vector $f_{i t}$ contains firm related characteristics like industry (two digit), size, size squared and the location of the firm (nine different states, "Bundesländer") in order to control for the ex-ante heterogeneity of firms. The vector $q_{i t}$ includes three dummy variables for each quarter of the reference date where the according workers are defined as PC workers or NPC workers; the first quarter is the base quarter and thus not included in the regression. Finally, $\epsilon_{i t}$ is an error term assumed to be independent of observed characteristics. The time index $t$ identifies the year since displacement and the index $i$ refers to individuals. The vector of primary interest is $\beta$, which captures the differences in the variable of interest between PC workers and NPC workers over the observation period.

The focus of this chapter lies in the differences in the earnings losses between boom and recession periods. To directly estimate this difference in difference (DiD) parameter and to test whether they differ significantly from zero, the samples from boom and recession periods are merged together and additional regressions are run for each variable of interest, separately for the sample of small and large firms. The regression has the

\footnotetext{
${ }^{12}$ This means that the individual earnings/wages are divided by the average earnings/wages of all workers at the reference date (i.e. year $=0$ ).
} 
following form:

$$
\begin{aligned}
W_{i t}= & \alpha+\left(R_{i} \cdot p c_{i} \cdot y_{t}\right)^{\prime} \beta^{R}+\left(R_{i} \cdot y_{t}\right)^{\prime} \gamma^{R}+\left(R_{i} \cdot x_{i}\right)^{\prime} \delta^{R}+\left(R_{i} \cdot f_{i}\right)^{\prime} \eta^{R} \\
& +\left(R_{i} \cdot q_{i}\right)^{\prime} \theta^{R}+\left(p c_{i} \cdot y_{t}\right)^{\prime} \beta+y_{t}^{\prime} \gamma+x_{i}^{\prime} \delta+f_{i}^{\prime} \eta+q_{i}^{\prime} \theta+\epsilon_{i t}
\end{aligned}
$$

$R_{i}$ is a dummy variable taking on the value one for the recession and the value zero for the boom. The DID parameter vector $\beta^{R}$ captures the additional earnings losses for workers displaced during a recession compared with workers displaced during a boom.

\section{$5 \quad$ Empirical Findings}

The descriptive part showed that workers displaced from large firms suffer on average a larger earnings loss when the displacement occurs during a recession than when it occurs during a boom. The opposite is true for workers displaced from small firms. However, these results may be driven by the ex-ante heterogeneity of workers or firms. The advantage of the regression framework presented above is that it explicitly controls for such heterogeneity among workers and firms. The estimation results for $\beta^{R}$ (and the corresponding t-values) are shown in tables 3 and $4^{13}$.

In order to better understand the DiD estimates, estimated first differences of all outcome variables ( $\hat{\beta}$ in the regression given by specification 1$)$ are presented as well. Figures 3 and 4 display the results graphically. The differences of each outcome variable are displayed on the vertical axis and the years since displacement on the horizontal axis. The year since displacement is marked with an asterisk, when the difference between boom and recession is statistically significant on the $5 \%$ level. The left column of the subfigures shows the estimated differences for large firms and the right column those for small firms. The solid line corresponds to the estimated differences from the recession period and the dashed line to the estimated differences from the boom period. Each difference between the boom values and the recession values in the subfigures of figure 3 and 4 corresponds to a DiD estimate in table 3 and 4.

\footnotetext{
${ }^{13}$ Full regression results are available from the author on request.
} 


\subsection{Main Results}

The upper panel of figure 3 shows the estimated earnings losses of displaced workers. During the first year after plant closure, displaced workers suffer a strong decline in earnings in the range of $23 \%$ to $34 \%$, depending on the size of the former employer and the business cycle. For all groups of workers the earnings losses get smaller over time but are still substantially higher than $10 \%$ even six years after displacement. The most striking difference between workers displaced from small firms (subfigure b) and workers displaced from large firms (subfigure a) is that for the former the earnings losses are higher during a boom than during a recession, whereas for workers displaced from large firms the results are the opposite.

Figure 3 and Table 3

As column one of table 3 shows, workers displaced from large firms face an earnings loss during the first post-displacement year which is 5.3 percentages points (p.p.) higher if the displacement occurs during a recession rather than during a boom. Six years after displacement the DiD still amounts to -2.7 p.p.; in other words, workers displaced from large firms in a recession suffer higher earnings losses than those displaced from large firms in a boom even in the long run. Workers displaced from small firms suffer earnings losses which are 4.3 p.p larger when the plant closure occurs during a boom rather than during a recession (column four of table 3). These DiD estimates decrease over time to 2.7 p.p four years after the displacement. Five years after the displacement the difference between boom and recession becomes insignificant. This provides first evidence supporting the hypothesis that workers displaced from small firms during a boom are treated differently by the labor market and suffer the highest earnings losses. One explanation for this finding could be that workers displaced from small firms and seeking new jobs during a boom carry a negative signal with them due to their displacement.

Interestingly, the results for Austria for the post-displacement years are in line with the findings of Jacobson et al. (1993) who did similar research with data from Pennsylvanian. For all workers the DiD estimates in earnings are insignificant for the six pre-displacement years. ${ }^{14}$ This implies that workers have no ex-ante differences in earn-

\footnotetext{
${ }^{14}$ The only exception is the significant $\mathrm{DiD}$ of $-2.7 \%$ four years before the displacement for workers displaced from small firms.
} 
ings after controlling for individual-specific and firm-specific characteristics, ruling out a selection explanation.

To identify the source of variation in the earnings losses, I split them up into the UP effect and the wage effect, accounting for the fact that a decline in earnings for one specific group of workers can arise either from a higher fraction of unemployed workers with zero work income or just from lower wages. Subfigure $c$ and $d$ of figure 3show that one year after displacement PC workers are faced with a $15 \%$ to $22 \%$ lower probability to be employed than NPC workers, depending on the size of the former employer and the business cycle. This is not surprising because, per definition, all PC workers lose their jobs. The difference in the UP between PC and NPC workers is more than halved during the second year and then decreases slowly thereafter to about $2.5 \%$ six years after displacement. Hence, a big part of the large earnings losses during the first postdisplacement year can be explained by the large fraction of PC workers that do not find a new job immediately.

Column two of table 3 shows that workers displaced from large firms have a 7 p.p. lower probability to find a new job during the first post-displacement year if the plant closure occurs during a recession rather than during a boom. This positive $\mathrm{DiD}$ in the UP decreases over time to 1.5 p.p. six years after the displacement. In addition to the lower probability of finding a new job during the first year, workers displaced from large firms during a recession earn 1.8 p.p lower wages than those displaced in a boom (column three of table 3 ). The positive $\mathrm{DiD}$ in wages becomes insignificant after the second year. Thus the higher earnings losses for workers displaced from large firms in a recession as opposed to boom are largely driven by the higher fraction of unemployed workers with zero earnings.

For workers displaced from small firms, things are different, as shown in columns five and six of table 3. In the first post-displacement year workers displaced in a recession have better chances of finding a new job than workers displaced in a boom and thus the according DiD is negative (column five). From the second to the fourth year after displacement workers displaced in a boom have better chances of finding a new job than those displaced during a recession. During the following two years the DiD estimates in the UP becomes insignificant. Therefore, the larger earnings loss during the first post-displacement year for workers displaced in a boom rather than during a recession is 
due to a combined effect of the higher probability of being unemployed and lower wages. In following three years the significantly higher earnings losses are mainly driven by the large wage decline, because the positive DiD in the UP imposes ceteris paribus larger earnings losses during a recession.

The separation of the earnings losses into a wage effect and an UP effect shows that, the fact that workers displaced from small firms suffer higher earnings losses during a boom instead of during a recession is largely due to the large reduction in wage. The same method shows that the main driving factor of the opposite phenomenon, that workers displaced from large firms suffer higher earnings losses during a recession as opposed to during a boom, is the larger fraction of unemployed workers with zero earnings.

Next, I will present the results from the separation of the wage effect into the selection and the net wage effect. The selection effect picks up differences in the composition of employed workers and sheds light on two different aspects. First, comparing the selection effect before and after the plant closure for one specific group of workers helps to understand if the composition of employed workers within this group is affected by the plant closure. Second, the estimated DiD between the selection effect during a boom versus during a recession helps to better understand the DiD estimates found for the wage effect. A positive $\mathrm{DiD}$ of the selection effect indicates that the fraction of reemployed high wage workers is larger during a recession than during a boom. The net wage effect at time $t$ captures the individual difference in wage $t$ years after the plant closure and the average wage in the two pre-displacement years.

Results for the first differences are presented in figure 4. The subfigures $a$ and $b$ of figure 4 show again the wage effect (the vertical axis is rescaled for better illustration), and the subfigures $c$ and $d$ show the regression results of $\overline{w a g e}_{i}$, which corresponds to the selection effect. Finally, the subfigures $e$ and $f$ show the regression results of $\left(w_{a g e} i t-\overline{w a g e}_{i}\right)$. This can be interpreted as the net wage effect. The estimated DiD and the corresponding t-values are given in table 4 .

Figure 4 and Table 4

First, I will discuss the results solely for workers displaced from large firms, subsequently I will discuss the results for workers displaced only from small firms. Results for workers displaced from large firms are presented in the subfigures in the left column of 
figure 4 and column one to three in table 4 . The results indicate that workers displaced from large firms suffer a 1.8 p.p larger wage decline during the first post-displacement year if the plant closure occurs during a boom rather than during a recession (column 1 of table 3 . In the second year workers displaced during a recession suffer a stronger wage decline than workers displaced during a boom, which leads to an insignificant DiD estimate for wages in the second year. In the last four years there are no significant differences in the wage effect between workers displaced during a boom versus those displaced during a recession. Subfigure $c$ shows that over the whole observation period there are no statistically significant differences in the selection effect between the boom and the recession. This implies that the composition of PC workers who find a new job is independent of the business cycle for workers displaced from large firms. Therefore, the larger wage decline during the first post-displacement year for workers displaced during a boom is induced by a larger net wage decline (subfigure $e$ ). In the last four observed years there are hardly any differences between boom and recession in the wage effect, the selection effect and the net wage effect. Therefore, the according DiD estimates are statistically equal to zero. The wage losses for workers displaced from large firms are only affected by the business cycle in the short run.

In the pre-displacement years the wage differences between PC and NPC workers decline slightly over time. One possible explanation for this finding is that large firms try to avoid an imminent bankruptcy by reducing the wages of their employees. Comparing the composition of workers (subfigure $c$ ) of the last pre-displacement year with the first post-displacement year shows that, on average, a worker who finds a new job directly after displacement has had higher wages in the two pre-displacement years than the average worker in the year directly before the plant closure. In other words, high wage workers displaced from large firms have somewhat better chances to find a new job in the first post-displacement year than low wage workers displaced from large firms, independent of the business cycle.

Now the results for workers displaced from small firms will be discussed, shown in the subfigures in the right column of figure 4 and the last three columns in table 4 . Workers displaced during a boom suffer a 5 p.p. larger wage decline during the first year than workers displaced during a recession (column 4 in table 4). Thereafter, the DiD estimates declines more or less continuously over time to 2 p.p five years after the 
displacement. In contrast to the findings for workers displaced from large firms, workers displaced from small firms suffer larger wage decline even in the long run if the plant closure occurs during a boom instead of during a recession.

The findings for the selection effect (subfigure $d$ ) show that if the plant closure occurs during a recession high wage workers find a new job first, whereas during a boom an average wage worker finds a new job first. This yields a positive estimated DID of about 2 p.p. for the selection effect from two to six years after the displacement, in contrast to the findings for workers displaced from large firms. Subfigure $f$ shows that workers displaced from small firms during a boom suffer a net wage decline of almost 5 p.p. during the first year, but no additional net wage decline during the next five years. Workers displaced during a recession suffer a yearly wage decline of around 1.2 p.p. during the first four years. The milder net wage decline of workers displaced during a recession rather than during a boom leads to significant positive DiD estimates in the net wage effect during the first three years after displacement. The DiD estimates become insignificant during the last three years.

During the first three post-displacement years, there are two reasons why workers displaced from small firms during a boom suffer a higher wage loss than those displaced during a recession. First, high wage workers have a harder time finding a new job if the plant closure occurs during a boom rather than during a recession. Second, workers displaced during a boom suffer a higher net wage decline during the first three years after the plant closure. From the fourth to the sixth post-displacement year the positive DiD estimates in wages are only due to the fraction of high wage workers who find a new job first, which is higher during a recession than during a boom.

Again, results indicate that the labor market treats workers displaced from small firms differently, depending on whether they are displaced during a boom or during a recession. In the short run all workers displaced during a boom are punished by higher net wage declines than workers who are displaced during a recession. It seems to be the case thought that only high wage workers are punished in the long run. Even six years after displacement, high wage workers displaced during a boom have more problems finding a new job than high wage workers displaced during a recession. This result may indicate that high wage workers are held most responsible for the bad performance of a firm which in turn leads to the plant closure. Low wage workers are also punished 
by larger net wage declines if they are displaced during a boom rather than during a recession.

Krashinsky (2002) showed that the difference between the earnings losses of laid off workers compared with the earnings losses of displaced workers found by Gibbons and Katz (1991) becomes insignificant after one controls for the size of the former and the new employer. To take this into account, I have run two regressions with the wage as dependent variable (specification 2) where the size of the new employer is included as an additional regressor. The results are shown in table 5 . The DiD estimates in wages for workers displaced from large firms are now insignificant over the whole post-displacement period. The only difference to the results where the size of the new employer is ignored, is that the DiD coefficient for the first year after displacement is insignificant too. This is even stronger evidence for the hypothesis that workers displaced from large firms do not carry a negative signal at all, as suggested by Gibbons and Katz (1991). Conversely, the DiD estimates for workers displaced from small firms are even larger when one includes the size of the new employer. In other words, the results found in this chapter are not affected by the size of the new employer.

\section{Conclusions}

Most previous empirical studies on plant closure focused on earnings losses at one specific point in the business cycle. Nakamura (2004) showed for the first time within the framework of a theoretical model that earnings losses are larger when the plant closure occurs in a boom period instead of in a recession period. To my knowledge there is no paper analyzing if there are different effects between workers getting displaced from small firms compared to large firms. The displacement is a stronger signal about individuals' productivity for workers getting displaced from small firms than from a large firm. Furthermore, there are different signals of getting displaced at the beginning of a boom period than at the beginning of a recession period.

In this chapter, I show that in Austria workers displaced from small firms suffer significantly higher declines in earnings when they lose their job at the beginning of a longer boom period than at the beginning of a longer recession period. The larger earnings losses in boom are hardly driven by the according larger declines in wages. 
This finding goes hand in hand with the findings from Nakamura (2004) for the United States. For workers getting displaced from large firms the results are opposite. These displaced workers suffer larger earnings losses when they get displaced at the beginning of a recession period. The difference between the boom and the recession is strongly driven by large differences in the UP, in contrast to the findings for small firms where the UP effect does not depend on the business cycle.

Separating the wage effect in a selection effect and a net wage effect gives evidence that workers displaced from small firms in boom get punished. Moreover it seems that high wage workers get punished heavier than low wage workers. For displaced workers from large firms and from small firms in recession there seems to be no such punishment. This is evidence that these workers do not carry a bad signal from the displacement, as proposed by Gibbons and Katz (1991). 


\section{References}

Abbring, J. H., van den Berg, G. J., Gautier, P. A., van Lomwel, A. G. C., van Ours, J. C., and Ruhm, C. J. (2002). Displaced Workers in the United States and the Netherlands. In P. J. Kuhn, editor, Losing Work Moving on: International Perspectives on Worker Displacement, chapter 2, pages 105-194. W.E. Upjohn Institute for Employment Research Kalamazoo, Michigan.

Addison, J. T. and Portugal, P. (1989). Job Displacement, Relative Wage Changes, and Duration of Unemployment. Journal of Labor Economics, 7(3), 281-302.

Baker, G., Gibbs, M., and Holmstrom, B. (1994). The Wage Policy of a Firm. The Quarterly Journal of Economics, 109(4), 921-55.

Barlevy, G. (2001). Why are the Wages of Job Changers So Procyclical? Journal of Labor Economics, 19(4), 837-78.

Bender, S., Dustmann, C., Margolis, D., and Meghir, C. (2002). Worker Displacement in France and Germany. In P. J. Kuhn, editor, Losing Work Moving on: International Perspectives on Worker Displacement, chapter 5, pages 375-470. W.E. Upjohn Institute for Employment Research Kalamazoo, Michigan.

Bowlus, A. and Vilhuber, L. (2002). Displaced Workers, Early Leavers, and Reemployment Wages. Working Paper 20015, University of Western Ontario, CIBC Human Capital and Productivity Project.

Dunlop, J. T. (1938). The Movement of Real and Money Wage Rates. The Economic Journal, 48(191), 413-434.

Farber, H. S. (1996). The Changing Face of Job Loss in the United States, 1981-1993. NBER Working Papers 5596, National Bureau of Economic Research, Inc.

Farber, H. S. (2005). What do we know about Job Loss in the United States? Evidence from the Displaced Workers Survey, 1984-2004. Economic Perspectives, pages 13-28.

Flaim, P. O. and Sehgal, E. (1985). Displaced Workers of 1979-83: How Well Have They Fared? Monthly Labor Review, 106(6), 3-16. 
Gibbons, R. S. and Katz, L. F. (1991). Layoffs and Lemons. Journal of Labor Economics, 9(4), 351-380.

Hamermesh, D. S. (1987). The Costs of Worker Displacement. The Quarterly Journal of Economics, 102(1), 51-75.

Hamermesh, D. S. (1989). What Do We Know About Worker Displacement in the U.S.? Industrial Relations, 28(1), 51-59.

Jacobson, L. S., LaLonde, R. J., and Sullivan, D. G. (1993). Earnings Losses of Displaced Workers. The American Economic Review, 83(4), 685-709.

Kletzer, L. G. (1998). Job Displacement. Journal of Economic Perspectives, 12(1), $115-136$.

Krashinsky, H. (2002). Evidence on Adverse Selection and Establishment Size in the Labor Market. Industrial and Labor Relations Review, 1(56), 84-97.

Kuhn, A. and Ruf, O. (2006). Austrian Social Security Database. IEW working paper no. 309, University of Zurich.

Nakamura, E. (2004). Layoffs and Lemons over the Business Cycle. Technical report, Harvard University, Department of Economics.

Ruf, O. (2004). Die Auswirkungen eines unfreiwilligen Jobverlustes auf die weitere Erwerbskarriere im Konjunkturzyklus. Unpublished diploma thesis, Institute for Empirical Research in Economics, University of Zürich.

Ruhm, C. J. (1991). Are Workers Permanently Scarred by Job Displacements? The American Economic Review, 81(1), 319-324.

Schwerdt, G. (2005). Labor Turnover before Plant Closure: 'Rats leaving sinking ship' vs. 'Captain throwing ballast overboard'? Unpublished working paper.

Stevens, A. H. (1997). Persistent Effects of Job Displacement: The Importance of Multiple Job Losses. Journal of Labor Economics, 15(1), 165-88.

Tarshis, L. (1939). Changes in Real and Money Wages. The Economic Journal, 49(193), $150-154$. 
Winter-Ebmer, R. (2001). Firm Size, Earnings, and Displacement Risk. Economic Inquiry, 39(3), 474-86. 


\section{A Appendix}

Figure 1: Business cycle

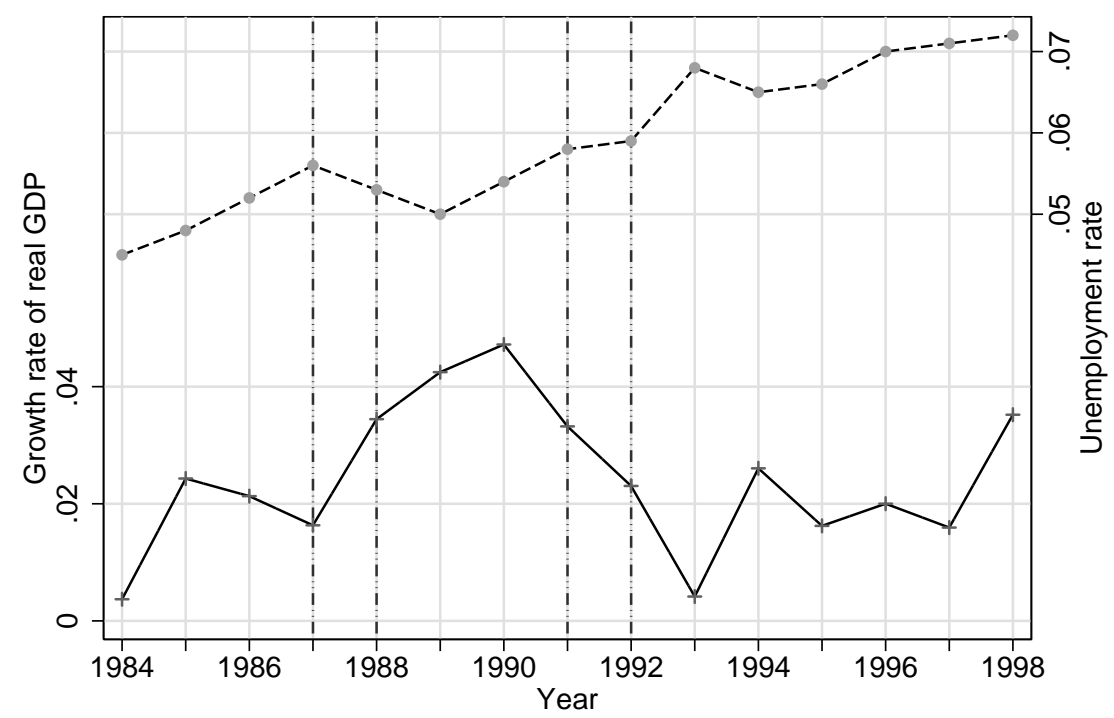

Growth rate of real GDP ------ Unemployment rate

Figure 2: Average differences in earnings over time
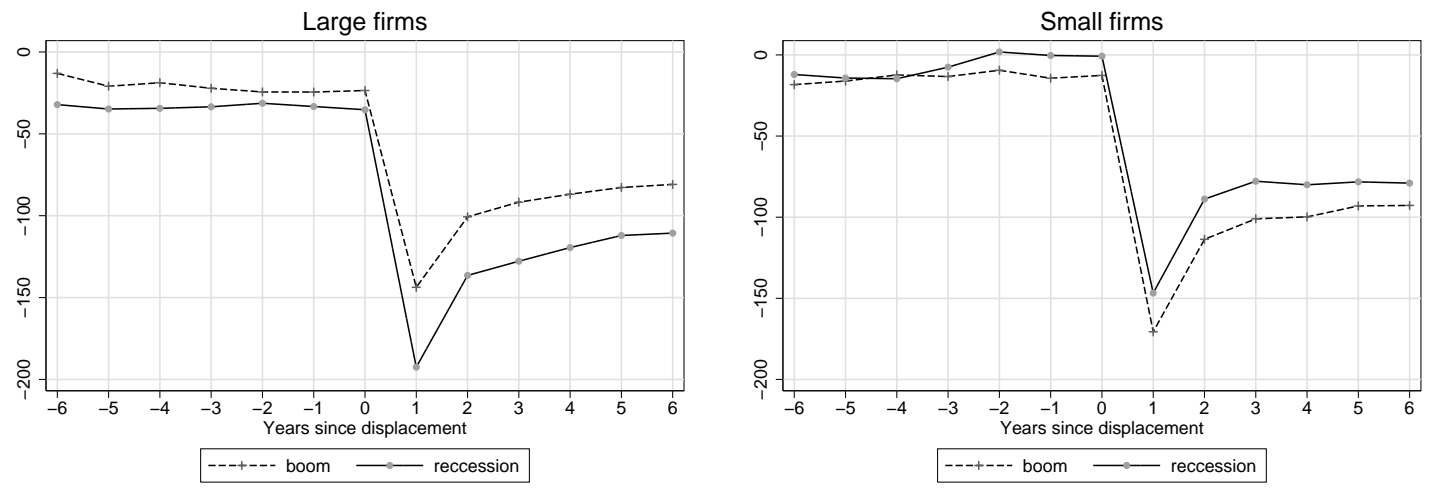

Source: Own calculations based on ASSD. 
Figure 3: Conditional differences over time
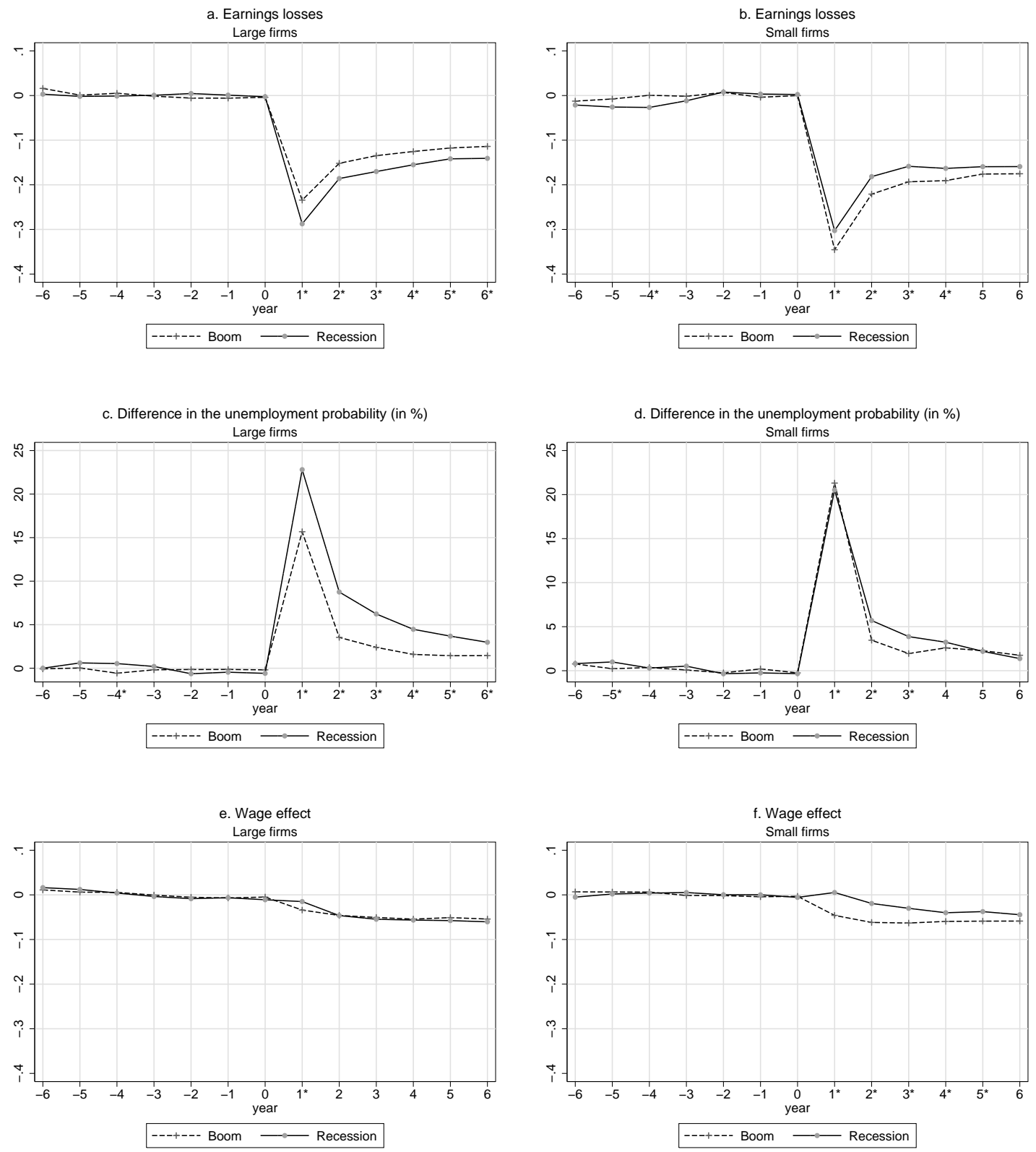
Figure 4: Conditional differences over time
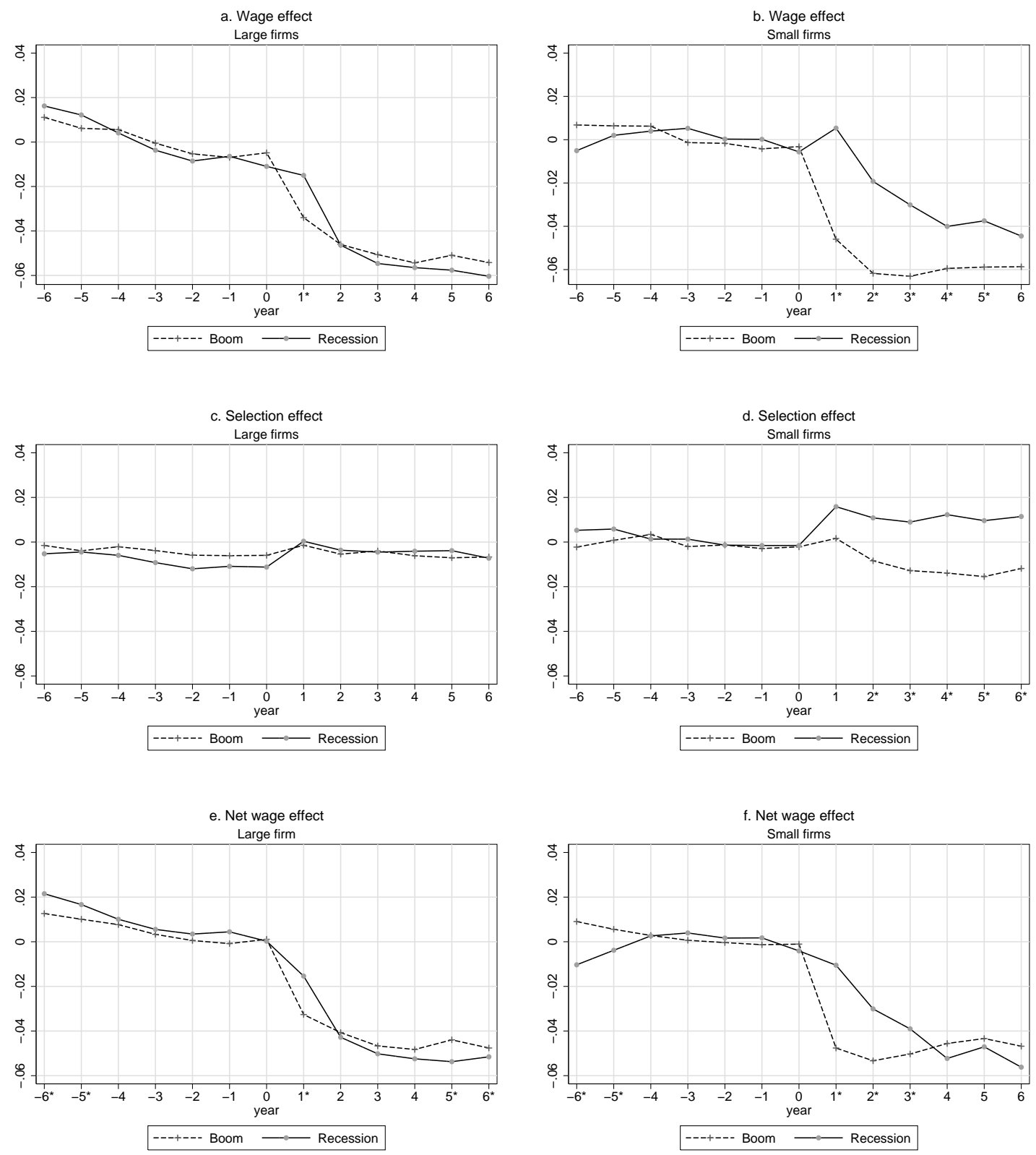
Table 1: Number of displaced workers by the size of their company

\begin{tabular}{|c|c|c|c|}
\hline \multicolumn{2}{|c|}{ Size of firm } & \multicolumn{2}{|c|}{ Number of $P C$ workers } \\
\hline & & boom & recession \\
\hline 1 & -4 & 5'977 (5'203) & 6’082 (5’337) \\
\hline 5 & $-\quad 9$ & 1’035 (472) & 1'144 (509) \\
\hline 10 & $-\quad 19$ & $582(135)$ & $621(155)$ \\
\hline 20 & $-\quad 49$ & $449(55)$ & $466(55)$ \\
\hline 50 & $-\quad 99$ & $167(8)$ & $223(12)$ \\
\hline 100 & $\begin{array}{l}-\quad 199\end{array}$ & $119(2)$ & $13(1)$ \\
\hline 200 & $\begin{array}{l}-\quad 499\end{array}$ & $40(1)$ & $0(0)$ \\
\hline 500 & $\begin{array}{l}-\quad 999\end{array}$ & $0(0)$ & $145(1)$ \\
\hline 1000 & + & $0(0)$ & $591(1)$ \\
\hline
\end{tabular}

Notes: The values in parentheses correspond to the number of firms. Source: Own calculations based on ASSD. 


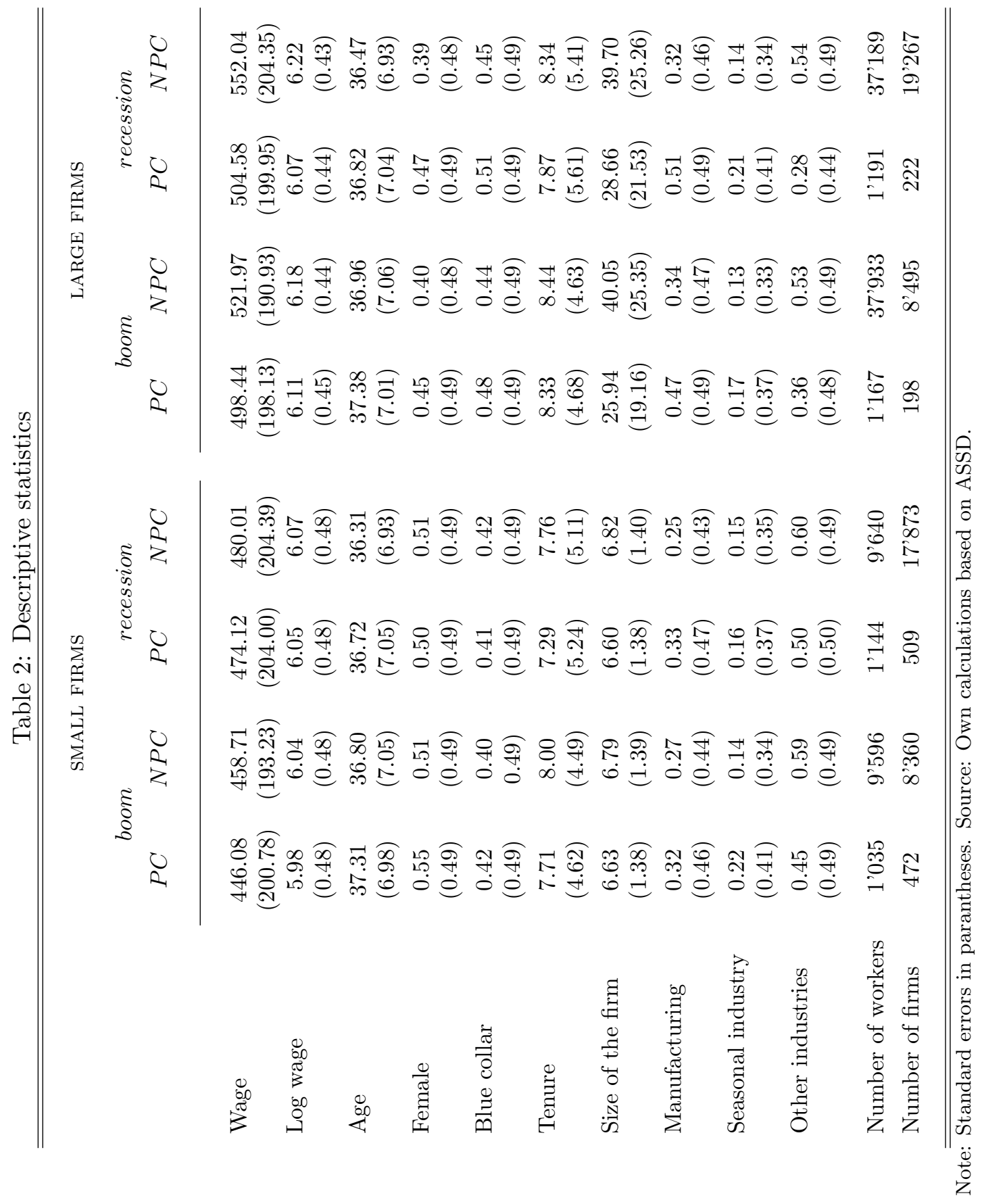


Table 3: Difference in differences: earnings, $U P$ and wages

\begin{tabular}{|c|c|c|c|c|c|c|}
\hline \multirow{2}{*}{$\begin{array}{l}\text { Sample } \\
\text { Dep. Variable }\end{array}$} & \multicolumn{3}{|c|}{ Large firms } & \multicolumn{3}{|c|}{ Small firms } \\
\hline & Earnings & $U P$ & Wages & Earnings & $U P$ & Wages \\
\hline Year -6 & $\begin{array}{c}-0.013 \\
(1.62)\end{array}$ & $\begin{array}{c}0.07 \% \\
(0.23)\end{array}$ & $\begin{array}{l}0.005 \\
(0.78)\end{array}$ & $\begin{array}{r}-0.009 \\
(0.87)\end{array}$ & $\begin{array}{c}0.00 \% \\
(0.01)\end{array}$ & $\begin{array}{l}-0.013 \\
(1.51)\end{array}$ \\
\hline Year -5 & $\begin{array}{c}-0.003 \\
(0.36)\end{array}$ & $\begin{array}{c}0.58 \% \\
(1.89)\end{array}$ & $\begin{array}{c}0.006 \\
(0.90)\end{array}$ & $\begin{array}{c}-0.018 \\
(1.79)\end{array}$ & $\begin{array}{l}0.73 \% \\
(2.05)^{*}\end{array}$ & $\begin{array}{c}-0.005 \\
(0.63)\end{array}$ \\
\hline Year -4 & $\begin{array}{c}-0.006 \\
(0.77)\end{array}$ & $\begin{array}{c}1.10 \% \\
(3.60)^{* *}\end{array}$ & $\begin{array}{c}-0.002 \\
(0.33)\end{array}$ & $\begin{array}{c}-0.027 \\
(2.68)^{* *}\end{array}$ & $\begin{array}{c}-0.09 \% \\
(0.25)\end{array}$ & $\begin{array}{c}-0.003 \\
(0.38)\end{array}$ \\
\hline Year -3 & $\begin{array}{l}0.002 \\
(0.24)\end{array}$ & $\begin{array}{c}0.38 \% \\
(1.25)\end{array}$ & $\begin{array}{c}-0.004 \\
(0.63)\end{array}$ & $\begin{array}{c}-0.010 \\
(1.01)\end{array}$ & $\begin{array}{c}0.40 \% \\
(1.12)\end{array}$ & $\begin{array}{l}0.006 \\
(0.73)\end{array}$ \\
\hline Year -2 & $\begin{array}{l}0.010 \\
(1.27)\end{array}$ & $\begin{array}{c}-0.49 \% \\
(1.61)\end{array}$ & $\begin{array}{c}-0.004 \\
(0.65)\end{array}$ & $\begin{array}{l}0.001 \\
(0.08)\end{array}$ & $\begin{array}{c}-0.14 \% \\
(0.39)\end{array}$ & $\begin{array}{l}0.001 \\
(0.13)\end{array}$ \\
\hline Year -1 & $\begin{array}{l}0.007 \\
(0.83)\end{array}$ & $\begin{array}{c}-0.32 \% \\
(1.05)\end{array}$ & $\begin{array}{c}-0.000 \\
(0.01)\end{array}$ & $\begin{array}{l}0.007 \\
(0.69)\end{array}$ & $\begin{array}{c}-0.48 \% \\
(1.33)\end{array}$ & $\begin{array}{l}0.003 \\
(0.44)\end{array}$ \\
\hline Reference date & $\begin{array}{l}0.001 \\
(0.08)\end{array}$ & $\begin{array}{c}-0.40 \% \\
(0.66)\end{array}$ & $\begin{array}{l}-0.007 \\
(0.58)\end{array}$ & $\begin{array}{l}0.002 \\
(0.11)\end{array}$ & $\begin{array}{c}-0.11 \% \\
(0.16)\end{array}$ & $\begin{array}{c}-0.003 \\
(0.23)\end{array}$ \\
\hline Year 1 & $\begin{array}{c}-0.053 \\
(6.61)^{* *}\end{array}$ & $\begin{array}{c}7.12 \% \\
(23.33)^{* *}\end{array}$ & $\begin{array}{c}0.018 \\
(2.69)^{* *}\end{array}$ & $\begin{array}{c}0.043 \\
(4.19)^{* *}\end{array}$ & $\begin{array}{c}-0.82 \% \\
(2.29)^{*}\end{array}$ & $\begin{array}{c}0.050 \\
(5.32)^{* *}\end{array}$ \\
\hline Year 2 & $\begin{array}{c}-0.034 \\
(4.25)^{* *}\end{array}$ & $\begin{array}{c}5.21 \% \\
(17.05)^{* *}\end{array}$ & $\begin{array}{c}-0.001 \\
(0.13)\end{array}$ & $\begin{array}{c}0.039 \\
(3.84)^{* *}\end{array}$ & $\begin{array}{c}2.20 \% \\
(6.14)^{* *}\end{array}$ & $\begin{array}{c}0.042 \\
(4.72)^{* *}\end{array}$ \\
\hline Year 3 & $\begin{array}{c}-0.036 \\
(4.43)^{* *}\end{array}$ & $\begin{array}{c}3.83 \% \\
(12.55)^{* *}\end{array}$ & $\begin{array}{c}-0.004 \\
(0.69)\end{array}$ & $\begin{array}{c}0.034 \\
(3.39)^{* *}\end{array}$ & $\begin{array}{c}1.89 \% \\
(5.27)^{* *}\end{array}$ & $\begin{array}{c}0.032 \\
(3.63)^{* *}\end{array}$ \\
\hline Year 4 & $\begin{array}{c}-0.030 \\
(3.71)^{* *}\end{array}$ & $\begin{array}{c}2.88 \% \\
(9.42)^{* *}\end{array}$ & $\begin{array}{c}-0.003 \\
(0.41)\end{array}$ & $\begin{array}{c}0.027 \\
(2.67)^{* *}\end{array}$ & $\begin{array}{c}0.60 \% \\
(1.69)\end{array}$ & $\begin{array}{c}0.018 \\
(2.05)^{*}\end{array}$ \\
\hline Year 5 & $\begin{array}{c}-0.024 \\
(3.02)^{* *}\end{array}$ & $\begin{array}{c}2.24 \% \\
(7.34)^{* *}\end{array}$ & $\begin{array}{r}-0.007 \\
(1.11)\end{array}$ & $\begin{array}{l}0.016 \\
(1.60)\end{array}$ & $\begin{array}{c}-0.11 \% \\
(0.31)\end{array}$ & $\begin{array}{c}0.020 \\
(2.23)^{*}\end{array}$ \\
\hline Year 6 & $\begin{array}{c}-0.027 \\
(3.30)^{* *}\end{array}$ & $\begin{array}{c}1.53 \% \\
(5.00)^{* *}\end{array}$ & $\begin{array}{r}-0.007 \\
(1.01)\end{array}$ & $\begin{array}{l}0.016 \\
(1.54)\end{array}$ & $\begin{array}{c}-0.41 \% \\
(1.14)\end{array}$ & $\begin{array}{l}0.013 \\
(1.41)\end{array}$ \\
\hline Observations & 4113911 & 4120802 & 3704037 & 1094892 & 1096914 & 956995 \\
\hline$R^{2}$ & 0.23 & 0.02 & 0.31 & 0.19 & 0.03 & 0.28 \\
\hline
\end{tabular}

Notes: $* *, *$ denotes significance at the $1 \%, 5 \%$ level respectively. T-values in parentheses. $U P$ is the unemployment probability times 100 .

Source: Own calculations based on ASSD. 
Table 4: Difference in differences: wages, selection effect, net wage effect

\begin{tabular}{|c|c|c|c|c|c|c|}
\hline \multirow{2}{*}{$\begin{array}{l}\text { Sample } \\
\text { Dep. Variable }\end{array}$} & \multicolumn{3}{|c|}{ Large firms } & \multicolumn{3}{|c|}{ Small firms } \\
\hline & Wages & $S E^{a}$ & $N W E^{b}$ & Wages & $S E^{a}$ & $N W E^{b}$ \\
\hline Year -6 & $\begin{array}{l}0.005 \\
(0.78)\end{array}$ & $\begin{array}{l}-0.004 \\
(0.64)\end{array}$ & $\begin{array}{c}0.009 \\
(2.63)^{* *}\end{array}$ & $\begin{array}{l}-0.013 \\
(1.51)\end{array}$ & $\begin{array}{l}0.007 \\
(0.85)\end{array}$ & $\begin{array}{c}-0.019 \\
(4.32)^{* *}\end{array}$ \\
\hline Year -5 & $\begin{array}{l}0.006 \\
(0.90)\end{array}$ & $\begin{array}{l}-0.001 \\
(0.16)\end{array}$ & $\begin{array}{c}0.006 \\
(2.01)^{*}\end{array}$ & $\begin{array}{l}-0.005 \\
(0.63)\end{array}$ & $\begin{array}{l}0.004 \\
(0.55)\end{array}$ & $\begin{array}{l}-0.010 \\
(2.15)^{*}\end{array}$ \\
\hline Year -4 & $\begin{array}{l}-0.002 \\
(0.33)\end{array}$ & $\begin{array}{c}-0.004 \\
(0.76)\end{array}$ & $\begin{array}{l}0.002 \\
(0.73)\end{array}$ & $\begin{array}{l}-0.003 \\
(0.38)\end{array}$ & $\begin{array}{l}-0.003 \\
(0.36)\end{array}$ & $\begin{array}{c}-0.000 \\
(0.07)\end{array}$ \\
\hline Year -3 & $\begin{array}{l}-0.004 \\
(0.63)\end{array}$ & $\begin{array}{l}-0.006 \\
(1.06)\end{array}$ & $\begin{array}{l}0.002 \\
(0.69)\end{array}$ & $\begin{array}{l}0.006 \\
(0.73)\end{array}$ & $\begin{array}{l}0.003 \\
(0.34)\end{array}$ & $\begin{array}{l}0.003 \\
(0.75)\end{array}$ \\
\hline Year -2 & $\begin{array}{l}-0.004 \\
(0.65)\end{array}$ & $\begin{array}{l}-0.007 \\
(1.22)\end{array}$ & $\begin{array}{l}0.003 \\
(0.93)\end{array}$ & $\begin{array}{l}0.001 \\
(0.13)\end{array}$ & $\begin{array}{l}-0.001 \\
(0.12)\end{array}$ & $\begin{array}{l}0.002 \\
(0.46)\end{array}$ \\
\hline Year -1 & $\begin{array}{l}-0.000 \\
(0.01)\end{array}$ & $\begin{array}{l}-0.005 \\
(0.97)\end{array}$ & $\begin{array}{l}0.005 \\
(1.71)\end{array}$ & $\begin{array}{l}0.003 \\
(0.44)\end{array}$ & $\begin{array}{l}0.000 \\
(0.07)\end{array}$ & $\begin{array}{l}0.003 \\
(0.71)\end{array}$ \\
\hline Reference date & $\begin{array}{l}-0.007 \\
(0.58)\end{array}$ & $\begin{array}{l}-0.006 \\
(0.53)\end{array}$ & $\begin{array}{l}-0.001 \\
(0.16)\end{array}$ & $\begin{array}{l}-0.003 \\
(0.23)\end{array}$ & $\begin{array}{l}-0.000 \\
(0.02)\end{array}$ & $\begin{array}{l}-0.003 \\
(0.39)\end{array}$ \\
\hline Year 1 & $\begin{array}{c}0.018 \\
(2.69)^{* *}\end{array}$ & $\begin{array}{l}0.001 \\
(0.22)\end{array}$ & $\begin{array}{c}0.017 \\
(4.73)^{* *}\end{array}$ & $\begin{array}{c}0.050 \\
(5.32)^{* *}\end{array}$ & $\begin{array}{l}0.013 \\
(1.49)\end{array}$ & $\begin{array}{c}0.037 \\
(7.29)^{* *}\end{array}$ \\
\hline Year 2 & $\begin{array}{r}-0.001 \\
(0.13)\end{array}$ & $\begin{array}{l}0.001 \\
(0.22)\end{array}$ & $\begin{array}{r}-0.002 \\
(0.65)\end{array}$ & $\begin{array}{c}0.042 \\
(4.72)^{* *}\end{array}$ & $\begin{array}{c}0.018 \\
(2.22)^{*}\end{array}$ & $\begin{array}{c}0.023 \\
(4.90)^{* *}\end{array}$ \\
\hline Year 3 & $\begin{array}{l}-0.004 \\
(0.69)\end{array}$ & $\begin{array}{l}-0.001 \\
(0.15)\end{array}$ & $\begin{array}{l}-0.004 \\
(1.06)\end{array}$ & $\begin{array}{c}0.032 \\
(3.63)^{* *}\end{array}$ & $\begin{array}{c}0.021 \\
(2.51)^{*}\end{array}$ & $\begin{array}{c}0.011 \\
(2.36)^{*}\end{array}$ \\
\hline Year 4 & $\begin{array}{l}-0.003 \\
(0.41)\end{array}$ & $\begin{array}{l}0.002 \\
(0.27)\end{array}$ & $\begin{array}{l}-0.004 \\
(1.25)\end{array}$ & $\begin{array}{c}0.018 \\
(2.05)^{*}\end{array}$ & $\begin{array}{c}0.025 \\
(2.99)^{* *}\end{array}$ & $\begin{array}{l}-0.007 \\
(1.43)\end{array}$ \\
\hline Year 5 & $\begin{array}{l}-0.007 \\
(1.11)\end{array}$ & $\begin{array}{l}0.003 \\
(0.44)\end{array}$ & $\begin{array}{c}-0.010 \\
(2.87)^{* *}\end{array}$ & $\begin{array}{c}0.020 \\
(2.23)^{*}\end{array}$ & $\begin{array}{c}0.024 \\
(2.81)^{* *}\end{array}$ & $\begin{array}{l}-0.004 \\
(0.80)\end{array}$ \\
\hline Year 6 & $\begin{array}{l}-0.007 \\
(1.01)\end{array}$ & $\begin{array}{l}-0.001 \\
(0.16)\end{array}$ & $\begin{array}{l}-0.004 \\
(1.15)\end{array}$ & $\begin{array}{l}0.013 \\
(1.41)\end{array}$ & $\begin{array}{c}0.022 \\
(2.58)^{* *}\end{array}$ & $\begin{array}{l}-0.010 \\
(1.91)\end{array}$ \\
\hline Observations & 3704037 & 3704037 & 3704037 & 956995 & 956995 & 956995 \\
\hline$R^{2}$ & 0.32 & 0.31 & 0.29 & 0.28 & 0.27 & 0.23 \\
\hline
\end{tabular}

Notes: $* *, *$ denotes significance at the $1 \%$ and $5 \%$ level respectively. T-values in parentheses. $U P$ is the unemployment probability * 100 . (a) $S E$ reports the selection effect given by $\overline{w a g e}$. (b) $N W E$ reports the net wage effect given by $\left(\right.$ wage $\left._{i}-\overline{w a g e}_{i}\right)$

Source: Own calculations based on ASSD. 
Table 5: DiD Wages, including the size of the new employer

\begin{tabular}{|c|c|c|}
\hline Sample & Large firms & Small firms \\
\hline Dep. Variable & Wages & Wages \\
\hline Year -6 & $\begin{array}{l}-0.003 \\
(0.45)\end{array}$ & $\begin{array}{l}-0.003 \\
(0.31)\end{array}$ \\
\hline Year -5 & $\begin{array}{l}-0.002 \\
(0.28)\end{array}$ & $\begin{array}{l}0.004 \\
(0.46)\end{array}$ \\
\hline Year -4 & $\begin{array}{r}-0.006 \\
(0.86)\end{array}$ & $\begin{array}{l}0.003 \\
(0.36)\end{array}$ \\
\hline Year -3 & $\begin{array}{l}-0.007 \\
(1.10)\end{array}$ & $\begin{array}{l}0.016 \\
(1.85)\end{array}$ \\
\hline Year -2 & $\begin{array}{c}-0.006 \\
(0.85)\end{array}$ & $\begin{array}{l}0.010 \\
(1.26)\end{array}$ \\
\hline Year -1 & $\begin{array}{c}-0.003 \\
(0.40)\end{array}$ & $\begin{array}{l}0.013 \\
(1.61)\end{array}$ \\
\hline Reference Date & $\begin{array}{c}-0.009 \\
(0.72)\end{array}$ & $\begin{array}{c}0.005 \\
(0.32)\end{array}$ \\
\hline Year 1 & $\begin{array}{l}0.007 \\
(0.96)\end{array}$ & $\begin{array}{c}0.058 \\
(5.65)^{* *}\end{array}$ \\
\hline Year 2 & $\begin{array}{c}-0.004 \\
(0.56)\end{array}$ & $\begin{array}{c}0.052 \\
(5.40)^{* *}\end{array}$ \\
\hline Year 3 & $\begin{array}{l}-0.008 \\
(1.10)\end{array}$ & $\begin{array}{c}0.041 \\
(4.27)^{* *}\end{array}$ \\
\hline Year 4 & $\begin{array}{r}-0.006 \\
(0.77)\end{array}$ & $\begin{array}{c}0.030 \\
(3.08)^{* *}\end{array}$ \\
\hline Year 5 & $\begin{array}{l}-0.008 \\
(1.06)\end{array}$ & $\begin{array}{c}0.034 \\
(3.43)^{* *}\end{array}$ \\
\hline Year 6 & $\begin{array}{l}-0.008 \\
(1.09)\end{array}$ & $\begin{array}{c}0.019 \\
(1.83)\end{array}$ \\
\hline Obs. & 3704037 & 956995 \\
\hline$R^{2}$ & 0.31 & 0.27 \\
\hline
\end{tabular}

